\title{
İslami Hassasiyetler Çerçevesinde Helal Turizm Uygulamalarına İlişkin Bir Değerlendirme: Helal Oteller ${ }^{1}$
}

Yrd. Doç. Dr. Özlem ALTUNÖZ SÜRÜCÜ Sinop Üniversitesi, Turizm İşletmeciliği ve Otelcilik Yüksekokulu, Sinop, e-posta: altunoz@sinop.edu.tr

Yrd. Doç. Dr. Hasan Selim KIROĞLU Sinop Üniversitesi, İlahiyat Fakültesi, Sinop, e-posta: hasanselimkiroglu@sinop.edu.tr

Öğr. Gör. Şaban KARGİGLİĞLU Sinop Üniversitesi, Turizm İşletmeciliği ve Otelcilik Yüksekokulu, Sinop, e-posta: skargiglioglu@sinop.edu.tr

Öğr. Gör. Selim KARAÇAĞA Sinop Üniversitesi, İlahiyat Fakültesi, Sinop, e-posta: skaracaga@sinop.edu.tr

\section{Öz}

Helal turizm kavramının Dünya'da sayısı hızla artan Müslüman turist pazarının, turistik ihtiyaçlarının fark edilmesi ve bu hassasiyetlere yönelik ürün ve hizmetlerin geliştirilmesi yolu ile ortaya çıktığı söylenebilir. Konu işletmecilik açısından ele alındığında; İslami hassasiyetleri olan bireylerin "helal turizm, helal otel, helal gida, helal aktiviteler" gibi konseptlerle faaliyet gösteren işletmelere yönelik yoğun talepte bulunduğu ve uygulamanın başarılı olduğu algısı oluşmaktadır. Ancak konu İslami açıdan bazı tereddütleri beraberinde getirmektedir. Nitekim pek çok ürün ve hizmeti bir arada bulunduran endüstride tüm iş ve işlemlerin İslam'a uygun yürütülmesi zordur. Bu çalışmanın amacı, tüketici şikâyetlerinden yararlanarak Türkiye'de faaliyet gösteren Helal otel işletmelerinin uygulamalarına yönelik mevcut durumu İslami açıdan ele almaktır. Araştırma sonucunda otel misafirlerinin otel hizmetlerine ilişkin şikâyetleri 13 grup altında toplanmış, Kuran-1 Kerim ve sahih hadisler ışığında İslami boyutuyla değerlendirilmiştir.

Anahtar Kelimeler: Helal Turizm, Helal Otel, Helal Ticaret, Müşteri Şikâyetleri, İslami Hassasiyetler.

\section{Önerilen Atıf:}

Altunöz Sürücü, Ö., Kıroğlu, H. S., Kargiglioğlu, Ş. ve Karaçağa S. (2017). İslami Hassasiyetler Çerçevesinde Helal Turizm Uygulamalarına İlişkin Bir Değerlendirme: Helal Oteller, Türk Turizm Araştırmaları Dergisi, Cilt.1, Sayı.1, ss. 64-77.

\footnotetext{
${ }^{1}$ Bu çalışma I. Uluslararası Helal Turizm Kongresi'nde bildiri olarak sunulmuştur.
} 


\section{Evaluating Halal Tourism and Islamic Sensitives: Halal Hotels}

Assistant Prof. Dr. Özlem ALTUNÖZ SÜRÜCÜ Sinop University, Tourism and Hospitality Management School, Sinop, e-mail: altunoz@sinop.edu.tr

Assistant Prof. Dr. Hasan Selim KIROĞLU Sinop University, Faculty of Theology, Sinop, email: hasanselimkiroglu@sinop.edu.tr

Lecturer Şaban KARGİGLIOĞLU Sinop University, Tourism and Hospitality Management School, Sinop, e-mail skargiglioglu@sinop.edu.tr

Lecturer Selim KARAÇAĞA Sinop University, University, Faculty of Theology, Sinop, email: skaracaga@sinop.edu.tr

\section{Abstract}

The concept of halal tourism has appeared as a result of having become aware of and developing products and services that take into account the sensitivities of the growing Muslim tourist market. When this issue is examined from a business management perspective, it is perceived that not only do individuals with Islamic sensitivities demand such services as "halal tourism, halal hotel, halal food, halal activities" in exceedingly high numbers, but that the provision of such these services has been successfully achieved. From an Islamic perspective however, this issue raises a number of doubts. In particular, it is difficult to manage every aspect of such a large industry that includes so many products and services in such a way that ensure all aspects conform to Islamic regulations. This study aims to investigate the current situation of Halal hotel management in Turkey from an Islamic perspective by examining consumers' complaints. The results of the study collected 13 types of complaints by hotel guests concerning hotel services, which were then Islamically evaluated in light of the Holy Qur' an and sahih hadiths.

Keywords: Halal Tourism, Halal Hotel, Halal Trade, Customer Complaints, Islamic Sensitivities.

\section{Suggested Citation:}

Altunöz Sürücü, Ö., Kıroğlu, H. S., Kargiglioğlu, Ş. and Karaçağa S. (2017). Evaluating Halal Tourism and Islamic Sensitives: Halal Hotels, Journal of Turkish Tourism Research, Vol.1, Issue.2, pp. 64-77. 


\section{GİRIŞ}

Dini inanışlar her zaman insanoğlunun davranışını şekillendiren, yaşam tarzını belirleyen, kararlarını yönlendiren en önemli motivasyon unsurlarından biri olmuştur. İlk çağlardan bu yana hissedilen bu etki 18-20. yüzyıllarda teknolojik gelişmeler, modern hayatın meydana getirdiği değişim, globalleşme gibi unsurların etkisiyle önemini kaybetmiş gibi görünmekteydi. Modernleşme ve sekülerleşme kuramcıları zamanla dinin toplumsal ve siyasal alanlardaki etkinliğinin ortadan kalkacağını, bireysel olarak da dini pratikler, ibadetler ve ritüellere katılımın gerileyeceğini savunuyordu (Küçükcan, 2005). Ancak 20. yüzyıla gelindiğinde sekülerleşme kuramının aksine dini unsurların yeniden insan hayatında öneminin artmaya başladığı görülmekte ve pek çok sosyolog tarafından kabul edilmektedir. Nitekim Berger 1999 yılında editörlügünü yaptığı "The Desecularization of the World" isimli kitabında önceden sekülerleşme kuramını destekleyen bir yayın yapmış olmasına karşın, düşüncelerinin değiştiğini ve sekülerleşen bir dünyada yaşadığımız düşüncesinin yanlış olduğunu ifade etmiştir.

Berger'e göre (1999) günümüz dünyası, bazı istisnalar hariç eskisi kadar, hatta bazı yerlerde eskisinden çok daha fazla dindardır. 21. yüzyıla gelindiğinde ise pazarlamacıların toplumda meydana gelen bu değişimleri fark ederek pazarlama faaliyetlerini bu doğrultuda yürüttüğü dikkati çekmektedir. Nitekim gıdadan kozmetiğe, tarımsal faaliyetlerden turizm hareketlerine kadar pek çok alanda tüm dinler için hassasiyetler temelinde ürün ve hizmetler üretildiği görülmektedir. Musevi tüketiciler için "Koşer (kosher) gıda", Müslüman tüketiciler için "helal gıda", Hristiyan tüketiciler için "Hristiyan gıda", Hindu tüketiciler için ise "Hindu Gıda" sertifika sistemleri dünyada görülen dine dönüş hareketinin bir sonucu olarak nitelendirilebilir.

Tüm bu uygulamalardaki amaç dini hassasiyeti olan bireyler için, söz konusu ürün ya da hizmetin üretim aşamasından tüketim aşamasına kadar tüm süreçlerde kullanılan malzeme ve yöntemlerin bireyin mensup olduğu dinin gereklerine uygun olduğu güvencesini sağlayarak müşteri çekme çabasıdır. Nitekim bu çabaların başarılı olduğu da bir gerçektir. Günümüzde pek çok işletme hizmet alanını değiştirerek bu sertifikasyon sistemlerinden birisine katılmakta ve hedef kitlesini yeniden belirlemektedir. Her inanç sistemine yönelik farklı uygulamalar olmasına karşın yapılan çalışmalar incelendiğinde akademinin özellikle Müslüman tüketicilere yönelik geliştirilen ürün ve hizmetlere odaklandığ görülmektedir. Müslüman tüketicilere yönelik bu ilginin çeşitli sebepleri vardır. Bunlar;

İslam Nüfusunda Meydana Gelen Hızlı Artış; Pew Araştırma Merkezinin (2015) yapmış olduğu bir araştırmaya göre 2010 yılında Dünya genelinde yaşayan Müslüman nüfus sayısı 1,6 milyar civarındayken 2050 yılında bu sayısının 2,8 milyara ulaşması beklenmektedir. Diğer yandan genç nüfus oranı ve doğurganlık gibi unsurlar göz önünde bulundurulduğunda Müslüman nüfusun artış hızının Dünya nüfusunun artış hızından yaklaşık iki kat daha hızlı olacağı ön öngörülmektedir (Pew Research Center, 2015).

İslam Ekonomilerinde Meydana Gelen Büyük ve Hızlı Değişim; Thomson Reuters ve Dinar Standard'ın raporuna göre 2015 yılında Dünyada 113 trilyon dolar civarında Gayri Safi Yurtiçi Hasıla elde edilirken, İslam İşbirliği Teşkilatına üye ve nüfusunun büyük çoğunluğu Müslümanlardan oluşan 57 ülkenin Gayri Safi Yurtiçi Hasılası 17 trilyon dolara ulaşmıştır. Bu miktar toplam Gayri Safi Yurtiçi Hasılanın ortalama \%15'ini temsil etmektedir (Thomson Reuters ve Dinar Standard, 2016).

İslami Değer ve İnanışların Yaşam Biçimini ve İş Yaşantısını Şekillendirmesi Yönündeki Artan Eğilim; Pew şirketinin 2015 yılında 42 ülkede yapmış olduğu Pew Küresel Tutum araştırmasına göre 
İslami ülkelerde yaşayan katılımcıların \%83'ü “dinin yaşamlarında çok önemli bir yeri olduğunu" belirtmişlerdir. Buna karşın Avrupa ülkelerinde yaşayan katılımcıların yalnızca $\% 21,5$ 'inin, Amerika'da yaşayan katılımcıların ise \%53'ünün aynı cevabı verdiği görülmektedir (Thomson Reuters ve Dinar Standard, 2016).

Bireylere, dini hassasiyetlerine uygun tüketim yapmalarına olanak verecek ürün ve hizmetler sunma ilk aşamada oldukça masum ve zararsız bir uygulama olarak görülebilir. Ancak bilinçsizce yapıldığı takdirde dini inanç sistemlerinin bir pazarlama aracı olarak kullanılmasının pek çok sakıncası da olabilir. İşletmelerin tedarik aşamasından üretim ve üretim sonrası aşamaya kadar ticari süreçlerinin tamamında aynı hassasiyeti göstermeleri dinin yozlaşmasının, farklılaştırılmasının, insanların en hassas duygusal yönelimlerinden biri olan inanç sisteminin zedelenmesinin önüne geçecektir. Tüm dinler için geçerli olan bu husustan yola çıkarak bu çalışmada İslami hassasiyetler çerçevesinde faaliyet gösteren Helal otel işletmelerinin mevcut durumu tespit edilmeye çalışılmıştır. Bu amaç çerçevesinde otel misafirlerinin otel hizmetlerine ilişkin şikâyetleri gruplandırılarak Kuran-ı Kerim ve sahih hadisler ışığında İslami boyutuyla değerlendirilmiş ve söz konusu işletmelerin uygulamasına yönelik öneriler sunulmuştur.

\section{HELAL TURIZZM VE İSLAM}

İnsanlar varoluşundan bu yana çeşitli sebeplerle seyahat etmişlerdir. Daha güvenilir yerlerde yaşama istek ve ihtiyacı, ticaret yapma, eğitim (Le Grand Tour) gibi çeşitli amaçlarla yapılan bu seyahatler esasında bildiğimiz anlamıyla turizm faaliyeti olarak nitelendirilmemektedir. Bununla birlikte dinlerin de insanların bir yerden bir yere seyahatinde etkili bir unsur olduğu bilinmektedir. Hristiyan misyoner ve Budist keşişlerin dinlerini yaymak üzere kıtalar arası seyahatleri, Müslümanların farz bir ibadet olarak Hac görevini yerine getirmeleri, dinler bağlamında önem arz eden merkezlerin belirli dönemlerde ziyaret edilmesi gibi seyahatler zamanla inanç temelli ziyaretlerin gelişmesine yol açmıştır. Ancak dini inanış ışığında önem arz eden bir merkezin ziyaret edilerek, ibadet ritüellerinin yerine getirilmesi ile tüm seyahat ve turizm hareketlerinde inancın gerektirdiği şekilde hareket edilmesi aynı şey değildir. Tekin (2014) din ve turizm arasındaki bu ilişkiyi iki formda ele alarak ayrıştırmıştır. Buna göre dini açıdan önem arz eden bir yeri ziyaret ederek ibadetlerini yerine getirmek İnanç turizmi kapsamında değerlendirilmekte ve burada destinasyonun niteliği ön plana çıkmaktadır. İkinci formda ise ziyaret edilen yerin niteliği önemli değildir. Ön plana çıkan durum; bireylerin hangi tür turistik etkinliğe katılırlarsa katılsınlar, inançlarının emir ve yasaklarına göre yaşamaları, bu emir ve yasaklara göre bir turistik davranış modeli ortaya koymalarıdır. Bu formda önemli olan olgu; turistik eyleme katılan bireyin dini inançlarının turistik tüketici davranışını etkilemesidir (Tekin, 2014). Nitekim Helal turizm kavramı da ikinci formda ele alınmakta ve tüketici davranışını şekillendiren İslam dininde helal olgusunu anlamak önem arz etmektedir.

Dini kavramlar sözlüğüne göre (Diyanet İşleri Başkanlığı, 2017) İslam "silm" ve "selam" kökünden türeyen bir kelimedir. Silm; barış, güven ve huzur, Selam ise; mutluluk, esenlik ve güvenlik anlamına gelmektedir. Kur'ân'a göre İslâm, kişinin kendisini yalnız Allah'a teslim etmesi, yalnız O'na kul olması, yalnız O'na ibadet etmesi demektir. İslam dinine mensup kişilerin temel bilgi kaynağı Kur'ân -1 Kerim ve hadislerdir. Kur'ân ve hadisleri günümüz hukuk diliyle yasa ve yönetmeliklere benzeterek ifade etmeye çalışmak konunun anlaşılması açısından faydalı olacaktır. Bilindiği gibi yasa bir eyleme ilişkin uyulması zorunlu kurallar bütünüdür. Yönetmelikler ise bu eylemin ne zaman, nerede ve ne şekilde yapılması gerektiğini ayrıntılı olarak açıklar. Bu kapsamda bir bilgi kaynağı olarak Kur'ân; Yaratan ve yaratılanlara ilişkin tanımların yapıldığı, varoluş, yaşam süreci ve sonrasına ilişkin bilgilerin verildiği, yaratanın 
niteliklerinin ve yaratılandan beklentilerin, emir ve yasakların, ödül ve cezaların ayetlerle açıkça ortaya konulduğu bir yasa şeklinde açıklanabilir. İslam peygamberi Hz. Muhammed (s.a.v.)'in aynı eylemlere ilişkin söz, tutum ve davranışları (Diyanet İşleri Başkanlığı, 2017) anlamına gelen hadisler ise yönetmelikler olarak tanımlanabilir.

İslami açıdan yapılan fiillere ilişkin hükümler; Vacip, Mendup, Mekruh, Haram ve Mubah olmak üzere 5 şekilde değerlendirilmektedir (Karaman, Bardakoğlu ve Apaydın, 1998). Bu hükümler kısaca şu şekilde açıklanabilir;

- Vacip: sözlükte "sabit, lâzım, var ve gerekli olan şey" anlamına gelmektedir. Birçok fıkıh âlimine göre farz ile aynı anlamda kullanılmaktadır. Hanefiler ise kati delillerle sabit olan hükme farz, zannî delille sabit olan hükme vacip diyerek ikili bir ayırım yapmışlardır. Farz olan bir emrin yapılmaması günahtır ve cezayı gerektirir.

- Mendup: teşvik edilen, yapılması kesin olmayan bir tarzda istenen, yani farz ve vacip olmayan davranışların genel adıdır. Sünnet ve Müstehap olarak iki şekilde ele alınır. Mendup olan bir davranışın yapılması hoş ve şirin karşılanırken yapılmaması herhangi bir günah ve ceza içermemekte, güzel olanı terk etme şeklinde değerlendirilmektedir.

- Mekruh: sözlükte "sevilmeyip kerih, nahoş görülen şey" demektir. Mekruh olan bir fiili gerçekleştirmek hoş karşılanmamakla birlikte cezayı gerektirmez.

- Haram: Yapılması kesin ve bağlayıcı bir ifade ve üslûpla yasaklanan fiiller için kullanılır. Bu fiillerin yapılması kesin bir günah ve cezayı gerektirir.

- Mubah: Helal ve Caiz terimleri genellikle Mubah ile aynı anlamda kullanılır. Sözlükte "açığa çıkan, açıklanan, serbest bırakılan şey" demektir. İslami açıdan kişinin yapıp yapmamada serbest bırakıldığ fiilleri ifade etmektedir.

İslam dinine mensup ve bu konuda hassas olan bireyler tüm iş ve davranışlarında yukarıda bahsedilen hükümler çerçevesinde hareket etmeye, günahlardan kaçınarak, helal kılınan şeyleri yapmaya özen gösterirler. Ancak burada ki en önemli husus helal ve haramların tayini noktasında ortaya çıkmaktadır. İlk devir İslâm hukukçuları özellikle "haram" hükmünü Allah'ın yetkisinde gördüklerinden haram ve helâl tabirlerini çok az ve dikkatle kullanmışlardır. Haram ve helâl kesin ve açık bir ayete/hadise dayanan ve sadece Allah'ın tayin ve takdir yetkisinde olan dinî bir hükümdür. Din âlimleri bu sebeple kendi ictihad ve yorumları sonucu ulaştıkları serbestliği veya sakıncayı ise "câiz ve câiz değil" tabirleriyle ifade etmeyi tercih etmişlerdir (Karaman vd., 1998).

$\mathrm{Bu}$ açıklamalardan yola çıkarak Helal turizm kavramının; Turizm içerisinde yer alan tüm faaliyetlerin (seyahat, konaklama, yiyecek-içecek, eğlence, vb.) tedarik, üretim, tüketim ve tüketim sonrası aşamalarının İslam'ın emir ve yasaklarına uygun olarak yürütüldüğü turizm şeklini ifade ettiği söylenebilir. Nitekim Helal sertifikalar Müslüman tüketicilere kullandıkları ürün veya hizmetin tamamıla şeriat kurallarına uygun olduğu güvencesini sunmakta (Samori, Salleh ve Khalid, 2016), Müslümanlar ise helal sertifikasına sahip işletmelerden bazı beklentiler içerisine girmektedir. 2012 Mayıs ve Haziran ayları arasında toplam 922 katılımcıyla yürütülen bir araştırmada Müslüman turistlere tatil için seyahat ettiklerinde sunulan şıklardan hangisinin kendileri için önemli olduğu sorulmuştur. Araştırma sonucunda katılımcıların $\% 66,8^{\prime}$ sinin tatil için seyahat ettiklerinde helal gıdaya, \%52,9'unun tatilin toplam fiyatına, \%49,1'inin ise tatil esnasında İslam'a uygun yaşantı sürmeye önem verdikleri görülmektedir (Dinar Standard, 2012). Diğer yandan Özdemir'in (2015) Muhafazakâr otel müşterilerinin otel işletmelerine 
yönelik beklentileriyle ilgili yapmış olduğu çalışmasına göre müşterilerin otel işletmesinde aradıkları özelliklerden bazıları aşağıdaki gibidir,

-Otelde erkek ve kadın müşteriler için ayrı havuzların bulunması,

-Otel restoranlarında haram içerikli ya da içeriği şüpheli yiyecek ve içeceklerin servisine izin verilmemesi,

-Muhafazakâr otellerde erkek ve kadın müşteriler için yeterli büyüklükte bir mescit bulunması,

-Otelin plajında kadınların denize girebilmeleri için ayrı alanların düzenlenmesi,

-Otelde kadın müşteriler için ayrılmış alanlarda kadın çalışanlar, erkek müşteriler için ayrılmış alanlarda erkek çalışanların görev alması,

-Kadın havuzlarının odalardan ve balkonlardan görülmeyecek şekilde düzenlenmesi,

-Ramazan ayında oruç tutan müşteriler için iftar ve sahur saatlerine uygun yemek düzenlemeleri yapilmasi,

-Otelde her türlü alkollü içecek servisinin yasak olması,

-Fitness, sauna, SPA ve spor salonlarının erkek ve kadın müşteriler için günün farklı saatlerinde ayrı düzenlenmesi,

-Otelde dini içerikli boş zaman değerlendirme aktivitelerinin yapılması.

Helal turizme yönelik talep her geçen gün artmasına ve son yıllarda hızla yükselen bir Müslüman pazara sahip olmasına karşın ISO (Uluslararası Standartlar Örgütü) tarafından yayınlanmış ortak bir standart bulunmadığından işletmelere Helal sertifikaları farklı ülkelerde farklı kriterler taban alınarak verilmektedir. Ülkemizde, Türk Standartları Enstitüsü helal uygunluk belgelendirmesini İslam Ülkeleri Standardizasyon ve Metroloji Enstitüsü (SMIIC) tarafından yayınlanan TS OIC/SMIIC 1: 2011 Helal Gıda Genel Kılavuzu standardına göre yapmaktadır (Türk Standartları Enstitüsü, 2017). Ancak bu belgelendirme yiyecek-içecek, helal kesim ve kozmetik gibi ürün gruplarıyla sınırlı kalmaktadır. Helal turizm sertifikasının ise ülkemizde çeşitli şirketler ve dernekler aracıllğıyla verildiği görülmektedir. Dünya Helal Birliği, Gıda ve İhtiyaç Maddeleri Denetleme ve Sertifikalama Araştırmaları Derneği (GIMDES), Adl Belge Danışmanlık Hizmetleri vb. kurumlar bunlardan bazılarıdır. Dünyada ve Türkiye'de helal turizm belgelendirmesine ilişkin güvenilir İslam âlimlerinin görüşleri doğrultusunda ortak kriterlerin bulunmaması söz konusu uygulamanın güvenirliliği ve homojenliği konusunda soru işaretleri oluşturmaktadır. Ayrıca gerek tüketicilerin helal otellerden beklentileri, gerekse Helal konseptiyle faaliyet gösteren otel işletmelerinin yapısı incelendiğinde beklentilerin ve bu beklentilere yönelik sunulan hizmetlerin üretim aşamasına kadar olan süreçle sınırlı kaldığ görülmektedir. Hizmet alımının şekli ve sonraki sürece ilişkin herhangi bir konu dikkati çekmemektedir. Bu yönüyle Helal turizmin yalnızca turizm aktiviteleri boyutuyla değil aynı zamanda ticari birer işlem olan turizm alışverişinin ticari anlamda İslam dini açısından ele alınması gerekmektedir.

\section{İSLAMA GÖRE TICARET AHLAKI}

Her turizm olayı aynı zamanda hizmeti üreten ve tüketen arasında bir alışverişin ortaya çıkmasına sebep olur. Diğer bir ifade ile satın alınan şey turistik bir hizmet olsa da bir alış veriş söz konusudur. Bu sebeple İslami açıdan alış veriş ve ticaretin nasıl olması gerektiği helal sertifikası ile faaliyet gösteren işletmelerin üzerinde durması, İslami hassasiyetleri çerçevesinde hareket eden Müslümanların ise ön planda tutması gereken bir diğer unsurdur. Çeşitli ayet ve 
hadislerde Müslümanların alış veriş konusunda dikkat etmesi gereken konular ele alınmıştır. Burada bu konular 4 başlık altında gruplandırılarak ele alınmıştır.

Her İşi Allah İçin Yapmak; Ticari açıdan bakıldığında işletmelerin nihai amacının kar elde etmek olduğu söylenebilir. İslami açıdan ise Müslümanın yaptı̆̆ı her işte ilk amacı Allah'ın rızasını gözetmek olmalıdır. Kar elde etmek ise ikinci amaç olmalıdır. Yalnızca Müslüman Pazarının ortaya çıardığı ekonomik fırsatlardan yararlanmak amacıyla dinin emir ve yasaklarının kullanılması İslami açıdan oldukça sakıncalıdır. Nitekim Kuranda yer alan Bakara Suresi 41. Ayet ve Maide suresi 44. Ayette (Türkiye Diyanet Vakf1, 2012) bu hususa kısmen değinilmiştir. "Ayetlerin para karşılığında satılmasının yasaklandığı bu surelerde Kuran ve ayetlerin bir ticaret kapısı olarak kullanılmaması gerektiği belirtilmiştir."

Güvenilir ve Dürüst Olmak; Müslüman her işinde dürüst ve güvenilir olmalıdır. Ancak ticaret söz konusu olduğunda karşıdakini aldatma sonucu kul hakkı da ortaya çıkacağından daha özenli davranılmalıdır. Nitekim çeşitli ayetler ve hadislerle ticarette dürüstlüğün önemi anlatılmaktadır. Hud suresi 112. Ayette (Türkiye Diyanet Vakfı, 2012) “... O halde, emrolunduğun gibi dosdoğru ol ..." denilmektedir.

Konu helal turizm kapsamında ele alındığında pek çok turistin henüz ürün veya hizmeti görmeden ve denemeden, broşürler veya internet sitesi üzerinden satın aldığı bilinmektedir. Otelde olmayan bir hizmeti varmış gibi göstermek, işletmeyi olduğundan büyük, geniş ve çeşitli göstermek, farklı yöntemlerle aslında sahile uzak bir işletmeyi yakınmış gibi fotoğraflamak, yanıltıcı bilgilendirmeler yapmak gibi tüm faaliyetler tüketicilerin aldatılmasına ve ticaretin İslami açıdan uygun olmamasına sebep olacaktır.

Temiz ve Hijyenik Olmak; Temizlik, İslam dininin üzerinde durulan önemli bir konudur. Müslümanın kendi bireysel temizliğine önem vermesi gerekliliği bir yana, ticaretin gerçekleştiği ortamın, kullanılan malzeme, araç ve gerecin temizlik ve hijyeni ticaretin İslami esaslar çerçevesinde yürütülmesi açısından oldukça önemlidir. Özellikle turizm faaliyetleri söz konusu olduğunda kişilerin işletmeye güvenerek ve temiz olduğuna inanarak konaklama yaptığı, yiyecek-içecek ve diğer ihtiyaçlarını giderdiği bilinmektedir. Çarşafların değiştirilmemesi, yer bezleri ile lavabo ve muslukların silinmesi, yiyecek-içecek malzeme ve materyallerinin temiz yıkanmaması gibi hususlar görünürde kişilerce fark edilmez. Ancak bunların kullanımı farklı hastalık ve rahatsızlıkları beraberinde getirebilir.

Fahiş Fiyat Yasağı ve Helal Kazanç; İslami açıdan bir malın gerçek değerinin çok üstünde bir fiyat karşılığında satılması uygun değildir. Fahiş fiyat olarak nitelendirilebilecek bu durum genellikle piyasada arz unsurlarının az olması talebin ise arza göre yoğun olması sonucu ortaya çıabilmektedir. Konuyu helal turizm açısından ele alacak olursak, İslami hassasiyetleri doğrultusunda tatil ihtiyacını gidermek isteyen bir tüketiciye, piyasada başka bir helal otel olmadığı veya helal otel sayısı az olduğu için aynı statüdeki diğer otellere nispeten çok daha yüksek fiyat politikası uygulamak kişilerin bu hassasiyetlerinden yararlanmak olacaktır. 


\section{TÜRKIYYEDE HELAL OTEL İ̧SLETMELERININ MEVCUT DURUMU}

Tüm Dünyada olduğu gibi Türkiye'de de Helal otel işletmelerinin sayısı hızla artmaktadır. Bu otellerin bir kısmı ticari hayatına helal otel olarak başlarken büyük bir kısmının ise ticari faaliyetinin şeklini bu yönde değiştirdiği görülmektedir. Diğer yandan 2009 yllında Booking, TripAdvisor, Tatil sepeti gibi online rezervasyon sistemlerine benzer şekilde helal konseptiyle faaliyet gösteren işletmelere rezervasyon yapma imkanı veren "HalalBooking" sisteminin kurulması sektörün kendi içerisinde ayrışmasına ve büyümesine olanak vermiştir.

HalalBooking, dini kurallara ve İslam inancına uygun iş seyahati, aile tatili veya turistik ziyaret gerçekleştirmek isteyenler için konaklama işletmelerine online ortamda, daha uygun fiyatlarla rezervasyon yapma imkanı sağlamaktadır. Platformda yer alan otellerin içerikleri incelendiğinde 'Helal oteller, muhafazakâr oteller, tesettür oteller ya da alkolsüz oteller' gibi farklı isimlerle anılan bu otellerde sadece bayanlara özel açık ve kapalı yüzme havuzlarına, spa ve sağlık merkezlerine yer verildiği görülmektedir. Muhafazakâr tatil köylerinin dışarıdan görülmeyecek şekilde tasarlanmış, sadece bayanlara özel plajlara, yüzme ve güneşlenme alanlarına sahip olduğu, birçok tesiste mütevazı kıyafetlerle aileler tarafından kullanılabilen karma aile plajlarının mevcut olduğu belirtilmiştir. Bu otellerde müşteriler, helal gidalar tüketmektedirler. Otellerde mescit bulunmakta ve misafirlerin ibadetlerini yerine getirmeleri için gerekli koşullar sunulmaktadır. Aile değerlerine uygun hizmet ve eğlencelerin yer aldığı otellerde tüm aktiviteler ve hizmetler İslam'ın iffet ve ahlaki değerleri göz önüne alınarak hazırlandığı belirtilmiştir.

HelalBooking adresine kayıtlı Türkiye' de faaliyet gösteren konaklama işletmeleri incelendiğinde Deniz tatil otelleri, Şehir otelleri, Termal oteller ve Havuzlu villalar olmak üzere 81 konaklama işletmesinin bulunduğu görülmektedir (HalalBooking, 2017). Diğer yandan sahip olduğu 2.447.985 üye ile şikayetvar Türkiye'nin en büyük online şikayet sitelerinden birisi durumundadır. Çeşitli kategorilerden şikâyetlerin yer aldığı sitede 2017 Ocak ayı itibariyle turizm kategorisinde 10958 şikâyetin, Otel-Tatil köyü kategorisinde ise 5925 şikâyetin olduğu görülmektedir. 2016 yılı için yapılan aramalarda ise HalalBooking'e kayıtlı 81 konaklama işletmesinden 29 tanesiyle ilgili toplamda 121 farklı şikâyet, 1 tanesiyle ilgili teşekkür mesaj1 bulunduğu görülmektedir. Diğer 51 konaklama işletmesiyle ilgili bir teşekkür ya da şikâyet mesajına rastlanmamıştır.

Söz konusu şikâyetler içeriğine göre 13 başlık altında gruplandırılarak aşağıda açıklanmıştır. Birden çok konuda şikâyet içeren metinler değinilen her konu için yeniden ele alındığından dolayı toplam şikâyet sayısı 161 şeklinde görülmektedir. Buna göre;

Personele İlișkin Şikâyetler; Konaklama işletmelerinde çalışan personele yönelik toplam 27 adet şikâyete ulaşılmıştır. Bu şikâyetler;

- Alınan siparişlerin yerine getirilememesi,

- Müşteri temsilcisine iletilen problemlerden bir çözüm elde edilememesi,

- Otelde kavga eden müşterilere müdahale edilmemesi,

- Uzun süre telefona bakılmaması,

- Müşterilerin herhangi bir ihtiyaçlarında yardım alamaması,

- Personelin müşterilere uygun olmayan şekilde hitap etmesi,

- İşletmelerde yetersiz personel çalışmasından kaynaklı alınan hizmet kalitesinin düşmesi,

- Personeller arasında bilgi akışının olmaması sonucu yaşanan aksaklıkların olması konularında ortaya çıkmaktadır.

Temizliğg İlişkin Şikâyetler; Konaklama işletmelerinin temizliği ile ilgili toplam 28 adet şikâyet bulunmuştur. Temizlik ile ilgili şikâyetlerin;

- Odalardaki banyonun iyi bir şekilde temizlenmemesi, 
- Otelin hamaminin temiz olmaması,

- Havuzlara girişte dışarıda giyilen ayakkabı ya da terlikle galoş kullanılmadan veya yıkanmadan girilmesi,

- Havuza çocuklarını getiren ailelerin çocuklarının tuvalet ihtiyacını havuzda gidermesi,

- Havlu değişimlerinin istenilen sıklıkta yapılmaması,

- Plajda tuvalet kabinlerinin bulunmaması nedeniyle insanların tuvalet ihtiyaçlarını denizde görmeleri gibi konularda ortaya çıktığı görülmektedir.

Fiziki İmkânlara Yönelik Șikâyetler; Konaklama işletmelerinin fiziki imkânlarıyla ilgili toplamda 19 adet şikâyet olduğu görülmektedir. Bunlar;

- Otel odalarının aileler için küçük olması,

- Havuzların otel kapasitesinin altında olması nedeniyle yetersiz kalması,

- Asansörlerin yetersiz olması,

- Kadınlar tarafını kapatan yelkenlerin kullanım amacına hizmet etmemesi,

- Klimaların bozuk olması, odalardaki mobilyaların eski olması,

- Açık büfenin yetersiz olmasından dolayı uzun kuyrukların oluşması,

- Otelde doluluk oranın düşük olmasından dolayı hizmetin eksik sunulması,

- Odalarda internetin olmaması,

- Sauna-masaj gibi hizmetler için randevu alınmasına karşın randevu saatinin geçmesine karşı bu hizmetlerden faydalanamamak,

- Kendi plajının - otoparkının olmaması şeklinde sıralanabilir.

Aktin Feshine İlişkin Șikâyetler: Aktin fesih edilmesiyle ilgili 13 adet şikâyet bulunmuştur.

- Aktin feshinden doğan ödemelerin yapılmaması,

- Vaat edilen hizmetin sağlanmaması sonucunda geri ödenecek tutarların ödenmemesi,

- Aktin fesih edilmesinin istenmesine karşın fesih işleminin yapılmaması gibi şikâyetler bunlardan bazılarıdır.

Güvenliğe Illişkin Șikâyetler: Güvenlikle ilgili 4 adet şikâyet incelenmiştir. İncelenen şikâyetlerde;

- Islak zemin levhası bulunmaması neticesince kaymaların yaşandığı,

- Havuzlarda cankurtaran olmadiğı,

- Saunada bulunan isitici demirlerin izole edilmemesi sonucunda yanıklara ve kazalara neden olmasi,

- Otelde kavga eden müşterilere müdahale edilmemesi sonucunda oteldeki diğer misafirlerin huzur ve güvenliğinin sağlanmadığı gözlemlenmiştir.

Aldatılmaya İlişkin Şikâyetler: Aldatılma ile ilgili 14 adet şikâyet bulunmuştur.

- İnternette belirtilenden daha yüksek fiyat talep edilmesi,

- İnternette belirtilen indirimlerin yapilmaması,

- Ücretsiz hizmet vaat ettiği halde hizmetin sağlanmaması,

- Devre mülk satışlarında yaşanan bilgilendirme eksikliği ve sözleşmelerde vaat edilenlerin yerine getirilmemesi,

- Yalan beyanlarla senet imzalatılması,

- Devre mülk satışı için bilinmeyen numaralardan defalarca arayarak rahatsızlık verilmesi

- Birden fazla kez kredi kartından para çekimi yapılması,

- Fazla para alımıyla ilgili talep ve şikâyetlere geri dönüş yapılmaması ve

- Provizyonda bekletilen paranın müşterinin hesabına geri ödenmemesi gibi durumlarla karşılaşılmıştır. 
Sunulan Hizmetten Memnuniyetsizliğe Iliskin Sikâyetler: Müşteri memnuniyeti ve müşteri tatmini ile ilgili 11 adet şikâyet bulunmuştur. Buna göre;

- Vaat edilen hizmetin yerine getirilmemesi,

- Grup olarak gelen misafirlere daha fazla ilgi gösterilmesi,

- Reklamlarda gösterilen hizmetin alınamaması,

- Konaklama işletmelerinin denize olan mesafesinin yanıltıcı olması,

- Küçük jestlerin yapılmaması,

- Belirli zamanlarda işletmelerin fazla rezervasyon yaparak kapasitesinden fazla müşteriye hizmet etmesi,

- Balayı müşterilerine özel bir hizmetin olmaması,

- Fiyat-kalite dengesinin olmaması,

- Çocuklu ailelerin isteklerine cevap verilmemesi gibi durumlar müşterilerin memnuniyetini düşürmüştür.

Fiyat Politikası ve Uygulamalarına İlişkin Sikâyetler: Fiyat politikaları ve uygulamalarıyla ilgili 6 adet şikâyet bulunmuştur. Buna göre;

- Anlaşılan fiyattan daha fazla para talep edilmesi,

- Türk lirası ile rezervasyon yapılamaması,

- Otel birimlerinde fiyatların oldukça yüksek olması,

- İnternet sitelerinde yayınladıkları fiyatların gerçeği yansıtmaması,

- İnternet sitelerinde çeşitli indirimlerin olduğu belirtilmesine karşın rezervasyon yapilırken bu indirimlerin uygulanmaması gibi şikayetlerden işletmelerin fiyat politikasıyla ilgili sıkıntıları olduğu söylenebilir.

Helal Konseptine Illişkin Șikâyetler: Konaklama işletmelerinin Helal Konsept uygulamalarıyla ilgili olarak 8 adet şikâyet bulunmuştur. Bunlar;

- Konaklama işletmelerinde tesettürlü müşteri yanında tesettürlü olmayan müşterilere de hizmet veriyor olmasi,

- Helal konsepte uygun bir şekilde düzenlenmeyen plaja sahip olması,

- İslam'a uygun temizliğin olmaması ve yemeklerin İslam'ın emir ve yasaklarına uymaması,

- Kadın ve erkeklerin aynı ortamda bulunması,

- Erkeklerin otelde bu konsepte uygunsuz olarak dolaşması,

- Havuzların kadın-erkek ayrı olmasına karşın bunun uygulanmaması ve karışık havuzların bulunması gibi konularda ortaya çıkmaktadır.

Boş Zaman Aktivitelerine Yönelik Şikâyetler: Eğlence ile ilgili 5 adet şikâyete rastlanmış olup bunlar genellikle animasyon ve boş zaman aktivitelerinin azlığı veya olmaması yönünde şikayetlerdir.

Otel Yönetimine İlişkin Șikâyetler: Şikâyetlerden 10 adedi, otel yönetimiyle ilgilidir. Burada;

- Otel yönetimin, muhafazakâr otel konseptiyle hizmet verdiğini savunmasına karşın aynı konseptte hizmet vermeyen bir işletmeyle aynı plajı kullanması,

- Personellerle iletişimde personellerin kötü bir üslupla konuşmalarından,

- Otelde gruplar varken bireysel gelen müşterilerle ilgilenilmemesi,

- Müş̧terilerin şikâyet ve taleplerine cevap bulamaması ve

- Devre mülklerde satış sonrası müşterilerle ilgilenilmemesi gibi sorunlar göze çarpmaktadır.

Yemeklere İlişkin Şikâyetler: Şikâyetlerden 12 adedi yemeklerle ilgilidir. Şikâyetler incelendiğinde,

- Yemeklerde çeşitliliğin ve lezzetin olmayışı,

- Yemeklerde kullanılan malzemelerin kalitesiz ya da bilinmeyen markalardan tercih edildiği, 
- Bir gün önceden kalan yemeklerin sağlıksız olarak tekrar sunulduğu,

- Yemek servis saatlerinden dolayı yaşanan olumsuzluklar,

Sağllk Tesisi Eksikliğine Yönelik Șikâyetler: Şikâyetler incelendiğinde sağllk tesisi eksikliğine yönelik 5 adet şikâyet bulunduğu görülmektedir. Bu şikâyetler;

- Otelde ve yakın çevresinde bir sağlık kurumunun bulunmaması,

- En yakın sağlık kurumunda yabancı bir doktor çalışması,

- Yaşanılan bir sağlık sorununda otel personelinin müşterilere yardımcı olmaması,

- Havuzlarda bone kullanılmaması ve uygun olmayan eylemlerin yapılması,

- Yemeklerden zehirlenme gibi konularda görülmektedir.

Yukarıda da görüldüğü üzere otel misafirlerinin helal otel işletmelerine yönelik en sık şikâyet ettiği 5 hususun sırasıyla; otelin oda ve genel kullanım alanlarının temizlik yetersizliği, personelin nitelik ve davranışları, fiziki imkânların yetersizliği, otel tarafından aldatılma, Aktin feshine ilişkin olduğu anlaşılmaktadır. Diğer yandan tekrarlanma sıklığı düşük olsa da otelin helal konseptiyle faaliyet göstermesine karşın farklı uygulamalar yürüttüğüne ilişkin şikâyetler dikkati çekmektedir. Nitekim bu sonuçlar incelendiğinde araştırma bulgularının Arpacı, Uğurlu ve Batman'ın (2015) yapmış oldukları çalışma bulgularıyla benzerlik taşıdığı görülmektedir. Arpacı vd. 2015 yılında yürüttükleri bir araştırmada benzer şekilde helal otel işletmelerine yönelik müşteri şikâyetlerini incelemiş ve otel müşterilerinin en sık şikâyet ettiği konunun, otel işletmelerinin uyguladığı yanıltıcı reklam, kampanya ve fiyat politikası olduğunu tespit etmişlerdir. Diğer yandan bu çalışmada farklı olarak otelin helal konseptine yönelik şikâyetlerin bulunması, helal otel uygulamasının denetimi konusunda eksiklik olup olmadığı sorusunu akla getirmektedir.

Söz konusu unsur dini hassasiyetler olduğunda, işletmelerin bu konuda daha bilinçli ve titiz davranması gereklidir. Ticarette inanç sistemini bir pazarlama aracı kullanmak kısa vadede bazı rekabet avantajları sağlayabilecek olmasına karşın, usulsüz ve uygun olmayan iş ve işlemler uzun vadede işletmenin de zarar görmesine sebep olacaktır. Bu açıdan araştırmadan elde edilen veriler sonuç ve öneriler kısmında İslami hassasiyetler çerçevesinde değerlendirilmiş ve işletmelere yönelik bazı öneriler sunulmuştur.

\section{SONUÇ VE ÖNERİLER}

Helal turizm gerek Dünyada gerekse Türkiye'de hızla gelişen yeni bir eğilim olarak değerlendirilebilir. Ancak bu hızlı gelişime karşın helal turizm sertifikalandırma sistemine yönelik ortak ölçüt ve usullerin bulunmaması farklı ülkelerde farklı uygulamaların görülmesine sebep olmaktadır. Diğer yandan söz konusu sertifikaya sahip işletmelerin denetimi hususunda da bazı soru işaretlerini beraberinde getirmektedir. Bu araştırmada müşterilerin helal otel işletmelerine yönelik şikâyetleri incelenmiş ve elde edilen veriler 13 başlık altında gruplandırılmıştır. Bu şikâyetler İslami açıdan ele alınarak neler yapılabileceği aşağıda tartışılmıştır.

İşletmelerin sunduğu hizmet ile hem çalışanlarına hem de müşterilerine güvenli ve huzurlu bir ortam oluşturması gerekmektedir. Ülkemizde tüm ticari işlemler ve tüketici hakları çeşitli kanun ve yönetmeliklerle korunmakta ve denetlenmektedir. Bu anlamda eksik ve kusurlu hizmet sunumu kanunen zaten ceza teşkil eden bir unsurdur. Ancak söz konusu helal oteller olduğunda yöneticilerin İslam'ın insana verdiği özel değeri de dikkate alarak bu konuda daha hassas davranması gerekmektedir. Dini hassasiyetler temelinde bir hizmet sunuluyorsa müşterilere hassasiyetler doğrultusunda hizmet vermek ve gerekli hallerde ona yardım etmek İslami açıdan da tavsiye edilen bir davranıştır. Nitekim Bakara suresi 195. ayette bu husus 
"Yaptığınız işleri güzel yapın; Allah işini güzel yapanları sever" (TDV, 2012) şeklinde belirtilmektedir.

Elde edilen bulgulardan yola çıkarak helal otel müşterilerinin işletmelerden İslami kurallara uygun bir ortamda tatil yapmaya yönelik ürün ve hizmetler beklediği ve bu otelleri bu amaçla tercih ettikleri görülmektedir. Bu ürün ve hizmetler yalnızca fiziksel ortam ve materyallerle sınırlı kalmamakta müşteriler ortam ve ambiyans olarak da bu hissiyatı yaşamak istemektedirler. Ancak yapılan şikâyetlerde söz konusu otellerin bu hassasiyeti taşımayan misafirlere de hizmet sunduğu, bu karma müşteri yapısının ise gerek kültürel gerekse davranış anlamında bir birleri üzerinde olumsuzluklar oluşturduğu anlaşılmaktadır. Örneğin bir müşteri şikâyetinde tatile giden bir misafirin kıyafeti konusunda uyarılmasının kendisi üzerinde oluşturduğu rahatsızlık ele alınmıştır. Başka bir müşteri şikâyetinde ise misafirin başka işletmelerle ortak ve karma plaj kullanımı sonucu yaşadığı rahatsızlık görülmektedir. Elbette her bireyin işletme seçim özgürlüğ̈̈ vardır. Ancak İslami hassasiyeti olan bireylere hitap eden ve bu doğrultuda hizmet vaat eden işletmelerin müşterilerin bu hassasiyetine özen göstermesi gerekmektedir. İslam kapsamında emir ve yasaklardan birisi de kıyafet ve harama bakmama konusunda görülmektedir. Nitekim bu husus Nur suresi 31. ayetinde erkeklere yönelik; “(Resulüm!) Mümin erkeklere, gözlerini (harama) dikmemelerini, ırzlarını da korumalarını söyle.", Nur suresi 32. ayetinde ise kadınlara yönelik; “Mümin kadınlara da söyle: Gözlerini (harama bakmaktan) korusunlar; namus ve iffetlerini esirgesinler. Görünen kısımları müstesna olmak üzere, ziynetlerini teşhir etmesinler. Başörtülerini, yakalarının üzerine (kadar) örtsünler..." şeklinde ifade edilmektedir (TDV, 2012).

Buradan hareketle İslami hassasiyeti doğrultusunda seyahat eden bir turistin özellikle tercih ederek İslami konseptli bir otelde kalması ve inanışı doğrultusunda tatilini geçirmek istemesi gayet normaldir. Diğer yandan kıyafeti dolayısıyla uyarıldığı için rahatsızlık duyan misafirin rahatsız olması da normaldir. Otel işletmelerinin bu gibi tatsız durumlarla karşılaşmamak için; müşteri profilini net bir şekilde ortaya koyması, gelen misafirleri söz konusu prensiplere ilişkin bilgilendirici broşürler hazırlaması; işletmede çalışacak personeli bu hassasiyetlere sahip veya uyum sağlayacak kişilerden seçmesi önerilebilir.

Helal konseptli otellerde yaşanılan sıkıntılardan biri de müşteri otele konaklamaya geldiğinde otelin reklamda tanıtılan ürün ve hizmet kalitesine sahip olmadığından ötürü konaklamaktan vazgeçmek istediğinde, otelin zorluk çıkarmasıdır. Müşteri bu anlaşmayı fesih etme hakkına sahiptir. Bu hak İslam'da, Hz. Peygamber'in: "Görmediği bir şeyi satın alan kimse, onu gördüğü zaman muhayyerdir" (Zeylaî, 1313) hadisiyle sabit olmakla beraber, Türkiye Cumhuriyeti 6502 sayılı "Tüketicinin Korunması Hakkındaki Kanun'un" sekizinci maddesiyle ve ilgili bazı maddelerle müşteri koruma altına alınmıştır. Diğer yandan aldatmak ve kusurlu mal satmak/kiralamak haksız kazanç olduğundan İslam'ca yasaklanmıştır. Bu husus Bakara suresi 188. ayette: "Mallarınızı aranızda haksız sebeplerle yemeyin." (TDV, 2012) şeklinde ifade edilmiştir. Söz verilen hizmeti alamayan müşterinin bu durumda fesih hakkını kullanması hem dinen hem de kanunen uygundur. Dini hassasiyetlerin ön plana çıtığı bu otellerde yalnızca ürün ve hizmetlerde değil ticaret noktasında da İslami kurallara uygun davranılması gerekmektedir. Uygulamada işletmelerin pek tercih etmemesine karşın bu tür durumlarda zorluk çıkarmadan müşteriye iade yaparak hem yapılan işlemin İslami kurallara uygun olacağı hem de müşterinin işletmeye olan güveninin artacağı düşünülmektedir. Ancak ön ödeme veya ücretin tamamını peşin ödemiş bir müşterinin, otelde herhangi bir kusur veya eksikliğin olmamasına rağmen farklı bir işinin çıkması ve programının değişmesi gibi bir durumda para iadesini talep etme hakkı yoktur. Zira sözleşme ve ödeme peşinen yapılmış ise oda, ödemeyi yapan müşteriye tahsis edildiğinden, diğer müşterilere kapatılmıştır. Bu şekilde otel para 
iadesini yapmaya rıza göstermedikçe geri ödeme yapılmaz ve müşterinin dinen ve kanunen bir hakkı bulunmaz.

Diğer yandan fahiş fiyat uygulamaları araştırmada karşılaşılan bir diğer sorundur. İslam’a göre alışveriş ve kira akitlerinde ticarete konu olan malların fiyatının belirlenmesi serbest piyasaya bırakılmıştır. Ancak İslam'ın ahlaki değerleri bu noktada önem arz etmektedir. İslami değerler ölçüsünde hareket etmek kaydıyla tüccar/mal sahibi piyasa oluşturmakta özgür bırakılmıştır. Ancak İslam, mal sahibinin haksız kazanç sağlayabileceği; müşteriyi aldatmak ve gerçek kârı söylerken yalan konuşmak suretiyle fazla para kazanmak (gabn-1 fâhiş) gibi durumların karşısında yer almıştır. Bu tür kazançlardan hem bireyin hem de toplumun ciddi şekilde olumsuz yönde etkilenmesi söz konusudur (Dalgın, 2012). Arzın sınırlı olduğu piyasalarda bu durumdan yararlanarak sunulan ürün veya hizmetin fahiş fiyatlarla satılması İslami olarak hoş karşılanmamaktadır. Bu sebeple Helal otel konseptiyle faaliyet gösteren işletmelerin tüm diğer ticari kuruluşlardan farklı olarak bu konuda daha fazla özen göstermesi gerekmektedir. İslam dininin hassasiyetlerine uygun hizmet verildiği vaat edildiğinden Helal otellerin piyasayı oluştururken, İslam'ın; ticarette net olma, dürüst davranma ve hoşgörülü olma ilkelerine riayet etmesi gerekmektedir. Aksi takdirde hileli ticaret yapılmış olunur ki; bu durum İslami açıdan sevilmeyen bir iş olarak kabul edilmektedir (Dalgın, 2012).

Helal otellere ilişkin şikâyetlerden bir diğeri genel ve özel kullanım alanlarının temizliği ile ilgilidir. Temizlik İslam dininin üzerinde durduğu konulardan birisidir. Fiziki ve manevi olmak üzere iki çeşit temizlik vardır. İslami açıdan manevi temizlik hali abdestli olmak ve helal yiyecek tüketme gibi örneklerle açıklanabilir. Fiziki temizlik ise; vücut, giyim kuşam, çevre ve gıdanın yıkanması gibi konularda temiz olmayı gerektirir. Bu husus bir hadiste: "Temizlik imanın yarısıdır" (TDV, 2013) şeklinde ifade edilmiş ve İslam'ın temizliğe verdiği önem çok açık bir ifadeyle bildirmiştir. Kur'an'da ise gidaların temizliği bahsine konu olan ayetler, helal gıdaların tüketilmesini emretmektedir. Nitekim Bakara suresi 168. ayette; "Ey insanlar! Yeryüzünde bulunanların helâl ve temiz olanlarından yiyin ..." ifadesiyle helal gıda dışındaki gıda tüketimi Müslümanlar için açıkça yasaklanmıştır.

$\mathrm{Bu}$ sebeple Helal otellerin, sundukları hizmetlerde temizlik ve hijyen açısından daha hassas olmaları gerekmektedir. Gelen müşterilerin İslami hassasiyetleri yüksek olduğundan gerek ibadet edilecek alanların, restoranların, dairelerin ve ortak kullanıma açık diğer mekânların gerekse yiyecek içeceklerin temiz olması önemlidir.

Son olarak otel işletmelerine yönelik şikâyetlerden birisinin de yiyecek-içecek çeşitliliğinin azlığı konusunda ortaya çıktığı görülmektedir. Ancak İslam dini malı gereksiz harcama, ölçüsüz bir şekilde sarf etme manasına gelen israfı yasaklamıştır. Genelde yiyecek ve içecek için kullanılan israf kelimesi, aslında ölçüsüzce yapılan her şey için kullanılabilir. Nitekim toplumlarda israfın en büyüğü gıda tüketiminde yapılmaktadır. Bu husus Araf suresi 31. ayette; "Yiyiniz içiniz; fakat israf etmeyiniz! Çünkü Allah israf edenleri sevmez." şeklinde anlatılmıştır. Kişinin her canı çektiğinde yemek yemesi de israf türlerindendir. Bir hadiste bu husus: "Canının çektiği her şeyi yemen, israftır." (TDV, 2013) şeklinde ifade edilmiştir. Bu sebeple özellikle helal otellerin şikâyetlere rağmen her şey dâhil sistemde faaliyet göstermesi, açık büfe yemeklerde gereğinden fazla çeşit ve miktarda yiyecek sunması İslami açıdan uygun değildir. Buna göre Helal turizm kapsamında hem otel işletmelerine hem de misafirlerine büyük sorumluluk düşmektedir. 


\section{KAYNAKÇA}

Arpacı, Ö., Uğurlu, K. ve Batman, O. (2015). Helal Konseptli Otel İşletmelerin Yönelik Yapılan Müşteri Şikâyetleri Üzerine Bir Araştırma, Bartın Üniversitesi İktisadi ve İdari Bilimler Fakültesi Dergisi, 6(11):181-198.

Berger, P. L. (1999). The Desecularization of the World: Resurgent Religion and World Politics. In P.L. Berger (Ed.), The Desecularization of the World: A Global Overview (pp. 1-18). Washington, Ethics and Public Policy Center.

Dalgın, N. (2012). Gündemdeki Tartışmalı Dini Konular-2, 2. Baskı, Samsun: Etüt Yayınları.

Dinar Standard. (2012). Global Muslim Lifestyle Travel Market 2012: Landscape \& Consumer Needs Study for Airlines, Destinations \& Hotels/Resorts Executive Summary, http://www. dinarstandard. com/travel-study/, Erişim Tarihi: 08.01.2017

Diyanet İşleri Başkanlığı. (2017). Dini Kavramlar Sözlüğü, http://www.diyanet.gov.tr/dinikavramlar/, Erişim Tarihi: 5 Ocak 2017

http://www.halalbooking.com

https://www.sikayetvar.com

Karaman, H., Bardakoğlu, A. ve Apaydın, H.Y. (1998). İlmihal I.- İman ve İbadetler, İstanbul: Diyanet İşleri Başkanlığı.

Küçükcan, T. (2005). Modernleşme ve Sekülerleşme Kuramları Bağlamında Din, Toplumsal Değişme ve İslam Dünyası, İslâm Araştırmaları Dergisi, 13:109-128.

Özdemir, H. (2015). Muhafazakâr Otel Müşterilerinin Otel İşletmelerinde Aradıkları Özelliklerin Belirlenmesine Yönelik Bir Araştırma, Yayımlanmamış Doktora Tezi, Gazi Üniversitesi, Eğitim Bilimleri Enstitüsü, Ankara.

Pew Research Center. (2015). The Future of World Religions: Population Growth Projections, 2010-2050. Http://Www.Pewforum.Org/2015/04/02/Religious-Projections-2010-2050/, Erişim Tarihi: 7 Ocak 2017

Samori, Z., Salleh, N.Z.M. and Khalid, M.M. (2016). Current Trends On Halal Tourism: Cases On Selected Asian Countries, Tourism Management Perspectives, 19:131-136.

Tekin, Ö. A. (2014). İslami turizm: Dünyadaki ve Türkiye'deki Genel Durum Üzerine Bir İnceleme, Uluslararası Sosyal Araştırmalar Dergisi, 7(29):750-766.

Thomson Reuters and Dinar Standard. (2016). State of the Global Islamic Economy Report2016/17, http://www.dinarstandard.com/islamic-growth-markets-investment-outlook-2015/, Erişim Tarihi: 7 Ocak 2017

Türk Standartları Enstitüsü. (2017). Helal Belgelendirme. https://www.tse.org.tr/tr/icerikdetay/ 2358/6898/ helal -belgelendirme-hizmetlerimiz.aspx, Erişim Tarihi: 8 Ocak 2017

Türkiye Diyanet Vakfı. (2012). Kuran-ı Kerim ve Açıklamalı Meali, 26. Baskı, Ankara: TDV Yayınları.

Türkiye Diyanet Vakfı. (2013). Hadislerle İslâm, 2. Baskı, Ankara: TDV Yayınları.

Zeylaî, Osman b.Ali. (1313). Tebyînü'l Hakâik Şerhu Kenzi'd-Dekâik. Bulak-Mısır: Matbaâtü’1 Kübra'l Emiriyye. 